УДК 316.454 .5

https://doi.org/10.31548/philolog2020.02.016

\title{
STRATEGIC AMBIVALENCE IN ILLOCUTIONARY SPEECH ACTS OF MODERN ENGLISH DIALOGIC DISCOURSE
}

\author{
I. V. GRABOVSKA, PhD in Philology, Associate Professor, \\ National University of Life and Environmental Sciences of Ukraine \\ E-mail: ivgrabovska@gmail.com \\ http://orcid.org/0000-0002-4229-6298
}

\section{V. MARIIKO, Master of Arts in English Philology, LLC “Maklai", Kyiv, Ukraine}

\begin{abstract}
The article focuses on the analysis of strategic ambivalence in illocutionary speech acts. The paper examines pragmatic properties of strategic ambivalent illocutionary speech acts in modern English dialogic discourse. It is suggested that strategic ambivalence is typical for situations when the speaker has certain perlocutionary intent and is willing to achieve it. Two cases of strategic ambivalence are distinguished: a) when perlocutionary intent is clear in the speaker's mind and not negotiable; b) when perlocutionary intent is clear in the speaker's mind and negotiable.
\end{abstract}

Key words: ambivalence, illocutionary speech act, strategic ambivalence, speech act theory, perlocutionary intention.

Introduction. Frequently interlocutors have various viewpoints on what a polite conversation is. For some of them politeness means being indirect. For the others politeness means directness, i. e., saying exactly what they mean. And once the investigation gets into the details, the differences of conversational strategies become more complex and, thus, we face the linguistic phenomenon called "ambivalence" [20]. Ambivalence is commonly understood as 1) the simultaneous existence of two opposed and conflicting attitudes or emotions; 2) the possibility of interpreting an utterance in two or more distinct ways; 3 ) vagueness or uncertainty of meaning.

In terms of our investigation, ambivalence is viewed as the indirectness of speech acts in which the speakers do not make clear which sequence of related illocutionary acts they intend to use. Further, ambivalence is understood as the case with negotiable interpersonal intent.

Speech activity like any other activities has its specific organization determined by goals and tasks of communication. Pragmatic approach to the study of language functioning enables the researchers [5;9] to get a better understanding of the communication mechanism and recognition of structural units which are aimed at the communicative contact associated with the organization of the process of verbal communication.

Recent researches and publications. Our daily communication presupposes that we perform speech acts. Taking into consideration the content of communication, it is possible to state that it may be identical, or almost identical, with the content intended to be communicated. Depending on the content intended to be embodied in communication, the meaning of the verbal and nonverbal means of interaction can be different.

Verbal communication can be considered from the point of view of the speech act theory [2; 17]. This theory argues that the notions of locution, illocution and perlocution should be distinguished. The illocutionary act is an act 
performed in saying something, as contrasted with a locutionary act, the act of saying something, and also contrasted with a perlocutionary act, an act performed by saying something [2, p. 113]. The idea of indeterminacy of illocutionary speech acts was suggested and developed by such scholars as J.L. Austin, K. Bach, R. M. Harnish, R. T. Lakoff, G. N. Leech, J. R. Searle, J. A. Thomas and A. Weiser.

The purpose of this research is to reveal pragmatic properties of strategic ambivalent illocutionary speech acts in modern English dialogic discourse. The research is conducted on the material of movies in English and the units analyzed are taken from the movies characters' dialogues.

To reach the objective of the research and accomplish its tasks, a number of general scientific methods (deduction, induction, analysis, and synthesis) as well as methods of linguistic analysis (pragmatic, discourse, speech act, and contextual analyses) are used.

Results. In daily interactions people often use one utterance meaning another. In this paper we will attempt to examine how uncertainty employed in interaction develops the concept of ambivalence. The concept of ambivalence in illocutionary speech acts, as defined by J. A. Thomas [23, p. 9], is ambivalence in which the speaker does not make clear precisely which of a series of related illocutionary acts is intended.

Although ambivalence is quite common in our daily interaction, why the speakers use it and what they expect from the addressees may vary from one case to another. In order to understand clearly why we employ ambivalence, we need to explore different cases of ambivalence and consider what factors make them different [14].

J. A. Thomas [24, p. 33] underlines several levels of intent in performing a speech act. Each intent can be defined as follows:

interpersonal intent: how the speakers want the addressees to consider their speech acts, or as what speech act the speakers want the addressees to regard their utterance.
- perlocutionary intent: what the speaker wants the addressee to accomplish by performing the speech act, or what perlocutionary effect the speaker wants to have on the addressee.

According to these viewpoints, ambivalence is understood as the case in which interpersonal intent is negotiable; the speakers leave unspecified what speech act they are performing, and leave it to the addressees how to take it.

On the other hand, in terms of perlocutionary intent, the cases vary. First of all, perlocutionary intent may or may not be clear in the speaker's mind. When it is clear, ambivalence is employed basically fo rsome strategic reason; in order to achieve certain perlocutionary intent, ambivalence is advantageous to the speaker. When it is not clear, ambivalence may be rather the reflection of unclearness in the speaker's mind. Thus, N. Tanaka [20, p. 128] defines two cases of ambivalence:

- strategic ambivalence: the speaker has certain perlocutionary intent in mind, and uses ambivalence strategically;

- genuine ambivalence: perlo-cutionary intent is not clear in the speaker's mind, and the unclearness is reflected as ambivalence.

Let us discuss some cases of strategic ambivalence to show a diversity of 'clearness' and 'negotiability' of perlocutionary intent in ambivalence.

Strategic ambivalence is further divided into two cases:

while interpersonal intent is negotiable,

- ocutionary intent is clear in the speaker's mind and not negotiable;

- perlocutionary intent is clear in the speaker's mind but negotiable.

In the first case, regardless of the addressee's reaction, the speaker wants to achieve a certain perlocutionary effect on the addressee, which is not negotiable; in other words, the motivation for ambivalence here is simply to present the intent in a less threatening manner, and the speaker does not have the intention to give the option to the addressees or to change their original intention. For example: 
(1) X: Would you come closer? I can hardly hear you.

$\mathrm{Y}$ : [comes closer to $\mathrm{X}$ ] (Be Kind Rewind, 2008).

So, in this very example $X$ wants to achieve a certain perlocutionary effect on $Y$, namely, he wants $Y$ come closer. The perlocutionary intent is not negotiable. The motivation for ambivalence here is to present the intent in a polite way.

In the second case, although the speakers have a certain perlocutionary intent, they are ready to negotiate it according to the addressee's reaction; the motivation for ambivalence here may be to probe the risk, and if the risk is high, to change the original intent to a less risky one, or if necessary, to abort it. Ambivalence may enable the speaker to keep the original intent from the addressee and to avoid the responsibility for it. For instance:

(2) X: Listen, I am in trouble. Can you help me?

\section{Y: What happened? (Meet Dave,} 2008).

In this case $X$ is ready to negotiate his perlocutionary intent according to Y's reaction. He understands that the risk is quite high and $Y$ can refuse. That is why $X$ uses a form of question to express a request.

As it was already stated, strategic ambivalence is used when the speaker wants to influence the addressee in a certain way. So, this type of ambivalence is used strategically since the speaker has a certain perlocutionary intent and wants to achieve a certain perlocutionary effect.

As there are different cases of strategic ambivalence and each case should be analyzed in detail.

First of all, let us study the examples where perlocutionary intent is clear in the speaker's mind and not negotiable. As it was already stated, within this kind of ambivalence, regardless of the addressee's reaction, the speaker wants to achieve a certain perlocutionary effect on the addressee, which is not negotiable. As the motivation for this kind of ambivalence is basically 'politeness' [11], it is frequently used in all spheres of everyday life and all types of conversations.

In the first example, Mr. Thomas $(X)$ who is a tax officer meets Emily Posa (Y) and offers her to sit:

(3) X: Would you have a seat, please, Ms. Posa?

Y: ... [takes a seat] (Seven Pounds, 2008).

Mr. Thomas's utterance is actually a question, but instead of answering it 'Yes' or 'No' Ms. Posa simply takes a seat. She realizes that the conversation is serious because she has some problems with taxes and Ms. Thomas being an official person came to deal with those problems. On the other hand, Mr. Thomas tries to be polite and friendly; he doesn't want to sound frightening, because he likes Ms. Posa and is aware of her heart disease. That is why with his utterance he makes it clear that the conversation will be long and serious, but he sounds politely and friendly.

Another example shows the same speaker's intention - the speaker doesn't want to be obtrusive, but at the same time performs a speech act with clear perlocutionary intent. Mr. Thomas comes to the hospital for the operation, and when everything is almost ready he goes outside to talk on the phone. In a while a nurse (X) comes to Mr. Thomas (Y) and politely reminds him to come to the surgery:

(4) X: Mr. Thomas, we're ready for you.

Y: [stands up and goes to the surgery] (Seven Pounds, 2008).

As is seen, the X's utterance doesn't presuppose the direct reply, it presupposes a certain reaction. So, it is quite obvious that perlocutionary intent of $X$ is clear and not negotiable and, moreover, it is clearly understood by $Y$.

Further examining of this kind of ambivalence shows that it does not presuppose or demand a direct reply - in the majority of cases it would be even inappropriately to give a direct reply without or instead of making a certain action (Davis 1979). For instance, Dr. House (X) going to the laboratory says to his team $(\mathrm{Y})$ : 
(5) $X$ : Are you coming? 2009).

Y: [go with X] (House M. D., 2004 -

As it was already stated, it would be inappropriate for the team to give some verbal replies without taking any action:

(6) $\mathrm{X}$ : Are you coming?

Y: Yes [still sitting and not going anywhere]??? (House M. D., 2004 - 2009).

Semantically, X's utterance is an alternative question, but the perlocutionary intended message is 'hurry up, come with me', and the doctors do not give a verbal reply - they simply take an action (go with $\mathrm{X}$.

Some other examples show the same pattern. Dr. Caddy $(X)$ to $\operatorname{Dr}$. House $(Y)$ :

(7) X: Can we talk? 2009).

Y: [goes to talk] (House M. D., 2004 -

Although semantically X's utterance is a simple question, its perlocutionary intended message is 'I want / need to talk to you (in private)'. And the message or the intent is clearly understood by $\mathrm{Y}$ : he stands up and goes to talk to $X$ without saying too much. It means that $X$ 's perlocutionary intent is quite clear for both communicators and is not negotiable.

In the next example Charlotte (X) addresses Will $(\mathrm{Y})$ :

(8) X: Didn't anyone ever tell you it was bad manners... to stare at a girl while she's eating? (Autumn in New York, 2000).

The conversation takes place at the restaurant; $X$ is hungry and eats her meals quickly without saying a word. $Y$ doesn't eat anything and stares at her so that she starts feeling uncomfortable. That is why her utterance, which is semantically a question, carries a definite perlocutionary intent: 'don't look at me like that when I'm eating, it makes me feel uncomfortable'.

Up to now we were analyzing cases where perlocutionary intent was clear in the speaker's mind and understood by the addressee. Such speaker's utterances were followed by appropriate addressee's reactions. The next case is interesting because of two reasons. First of all, because in this very case the addressee pretends he didn't understand the speaker's perlocutionary intent and thus makes it quite negotiable. Secondly, here we have the opportunity to talk about the role of idioms and metaphoric usage of strategic ambivalence. Mr. Thomas $(X)$ and a blind beef salesman $(Y)$ are talking on the phone; the conversation is not very friendly, it is tense:

(9) X: Do you even know what colour the ocean is? Do you??

Y: It's blue, sir (Seven Pounds, 2008).

Let us start interpreting from $X$ 's utterance. It should be said that $X$ is not aimed at being polite with $Y$. On the contrary, he expresses a humiliating remark that his interlocutor is blind and can't live a full life. So, in this context it is quite understood that X's utterance was intended not as a simple question that demands a direct answer 'yes' or 'no'. It was intended as something else, as it follows from the context of the situation itself and, moreover, from the meaning of the utterance which was used metaphorically. We can think of the perlocutionary intended message disguised in the verbal display of the utterance: it is 'you can't live a full life because you are blind'.

As for $Y$, he uses a strategy of 'misunderstanding' in order to get himself out of the unpleasant situation. He pretends he didn't get the message of X's illocutionary speech act, didn't understand $X$ 's perlocutionary intent to humiliate him. Although it seems that Y's reaction is not appropriate for X's utterance, in fact it is more suitable for $Y$ himself because he managed to avoid humiliation. Thus, reacting in such a way to X's utterance (where perlocutionary intent was not negotiable) $\mathrm{Y}$ turned the perlocutionary intent into negotiable one.

We have analyzed the case when the addressee pretended he didn't understand the speaker's perlocutionary intent, while, in fact, he actually did. Now, let us move on to the examples of ambivalent illocutionary speech acts where the speaker's intent may not be understood by the addressee.

The speaker's intents at different levels 
may not always be understood by the addressee. It means that the speaker who had a certain perlocutionary intent in mind and wanted to influence the addressee in a certain way did not reach success in making the addressee take an action because the last did not actually get the perlocutionary meaning of the speaker's illocutionary speech act. The following example is the conversation between Ricky Fitts $(X)$ and his mother $(Y)$ :

(10) X1: Have you seen my jacket, Mom?

Y1: No, I haven't. You can take your raincoat.

X2: Oh, yes. Thank you. [going outside without one]

Y2: You can take your raincoat because it's raining outside.

X3: I see. [takes his raincoat] (American Beauty, 1999).

The form "You can..." here is ambivalent; as J. Leech [12, p. 122] points out, the form allows various interpretations. The statement beginning with "You can" is an appropriate means of softening the effect of an impositive. It can best be regarded as a tentative version of $\mathrm{You}$ must: by pointing out the ability of the addressee to do the task, the speaker in effect proposes that the addressee does it. As it is seen in the example (10), "You can" carries the implicature 'You do not have to', and thus offers the addressee to ignore the hint. So, its politeness derives from its ambivalence: its sense allows it just as easily to be a recommendation or a piece of advice (an illocution for the benefit of the addressee) as to be an impositive'.

In the example above, because of the form "You can...", $\mathrm{X}$ interprets $\mathrm{Y} 1$ as a piece of advice or rather as an offer, thinking that $Y$ tries to retrieve her not knowing where the jacket is. As $X$ is not concerned too much about wearing a raincoat instead of a jacket, he simply responds "Thank you" to the considerate offer and wants to go out without a raincoat (X2).

However, Y's following utterance (Y2) makes $X$ realize that $Y 1$ was actually not an offer, but more close to a directive. Although $Y$ uses the same form "You can...", the fact that she says the utterance twice makes a cumulative effect, the repetition makes the actual perlocutionary intent clearer. $X$ reassesses $Y$ 's previous utterance, accepts it as a directive, and complies with her perlocutionary intent (wears a raincoat).

In the example (10), although the speaker has the interpersonal intent to present her utterance in a less imposing manner, the perlocutionary intent is not actually negotiable, which is not understood by the addressee. The negotiability of the interpersonal intent disguises the perlocutionary intent. The possibility of being misunderstood is a disadvantage of ambivalence [8].

The further example is another evidence to support the statements argued above. Charlotte's granny Dolly $(X)$ is talking to Will (Y) about Charlotte:

(11) Y: Look, Dolly...

$\mathrm{X}$ : Leave her alone! She's sick... Will, she's really sick (Autumn in New York, 2000).

It is obvious that $X$ 's perlocutionary intent is to make $Y$ leave her granddaughter. Impositive "Leave her alone!" is reinforced with the help of the further hint "She's sick", which probably means that $X$ has serious reasons for her demand. Unlike the previous example with "You can" that carries the implicature 'You do not have to', here we have the implicature 'You have to'. And thus, it is understood that $Y$ is not allowed to ignore the hint.

Moreover, $X$ repeats her last utterance addressing directly to Y: "Will, She's really sick", which indicates that the situation is really very difficult and it would be better for Charlotte if $Y$ leaves her. X's last utterance ("Will, She's really sick") makes $Y$ realize that her previous utterance was not simply a statement but actually a directive. Although $X$ uses the same form, the fact that she says the utterance twice makes a 'cumulative effect' mentioned above. It means that repeating her utterance $X$ makes her perlocutionary intent more distinct. 
The same 'cumulative effect' can be found in the next example of ambivalent illocutionary speech acts. A patient $(X)$ is talking to Dr. Wilson $(Y)$ and Dr. Cameron (Z):

Z]

(12) X1: Why she is here? [to $Y$ about Y1: She helps me with the prescriptions.

Z)

X2: Why, he treats me incorrectly? (to

Z1: Oh, no, no.

Y2: No.

X3: Then, why she is here? (House M. D., $2004-2009$ ).

The context of the conversation is the following: $X$ is a patient and $Y$ is her doctor. $Z$ comes to help $Y$ with the prescriptions, and that is the reason why $X$ starts feeling frightened and embarrassed. Embarrassed because she got used to her doctor and at the moment she doesn't know how to react and behave; frightened because now that her doctor needs someone else's help, she thinks that she has some serious complications.

On the one hand, we can suppose that $X$ 's first utterance (X1), having the particular perlocutionary intended meaning, was not understood by $Y$ as he took it as a simple question. X's final utterance (X3) made her perlocutionary intent clear: $X$ wants $Z$ to leave. Thus, utterance $X 1$ can be viewed as a case of strategic ambivalence where the speaker's perlocutionary intent was not understood by the addressee. On the other hand, we can assume that utterance $\mathrm{X} 1$ was performed simply in order to get information about $Z$ coming. Then utterance $X 1$ will be regarded as a simple question while utterance $\mathrm{X} 3$, having practically the same form as $\mathrm{X} 1$, will be viewed as the case of strategic ambivalence where the perlocutionary intent is clear in the speaker's mind and not negotiable.

Another example shows how the addressee who did not understand the speaker's perlocutionary intent fails to maintain a successful communication. This is a piece of conversation between a secret agent of the British intelligence $(X)$ and $M r$. Hawthorne $(Y)$ who has just returned from the mission in Jamaica. They discuss the drawings of secret weapons:

(13) Y1: What did the Prime Minister say, sir?

$\mathrm{X} 1$ : He said some of these drawings reminded him of a gigantic vacuum cleaner. Makes you shiver, doesn't it?

Y2: No, it was 92 degrees in Jamaica yesterday (Our Man in Havana, 1959).

In this very case X's ambivalent illocutionary speech act "Makes you shiver, doesn't it?" (X1) carries the perlocutionary intended message 'striking, impressive, and astonishing' (talking about the drawings of secret weapons). It is obvious that $\mathrm{X} 1$ is also used metaphorically, but what is important here is that $Y$ didn't manage to understand $X$ 's perlocutionary intent and thus failed to maintain a successful communication. His replica "No, it was 92 degrees in Jamaica yesterday" (Y2) is inadequate and shows his misunderstanding of the question which he took literally.

The further example is also sufficiently evident of the statement that misunderstanding of the speaker's perlocutionary intent (hidden in ambivalent illocutionary speech act) leads to failure in maintaining a good communication. Mr. Fletcher $(\mathrm{X})$ is talking to Jerry $(\mathrm{Y})$ :

(14) X: And you think it's funny, yeah?

Y: ... well, yes (Be Kind Rewind, 2008).

The matter is that $X$ is the owner of a shop, while $Y$ is his younger assistant. $X$ is quite conservative about everything concerning his shop. And $\mathrm{Y}$, on the contrary, tries to apply new marketing technologies to attract more customers. $X$ doesn't approve Y's methods and wants to sober him down by his utterance. But $Y$ fails to understand its meaning and X's perlocutionary intent correctly. He takes it as a simple question and answers it "Yes". Later, this reply will be taken by $X$ as a jeer and it will make their relations tense and lead to further misunderstandings.

Now, let us turn to the analysis of the examples where perlocutionary intent is clear 
in the speaker's mind but negotiable. Although the speakers have a certain perlocutionary intent, they may be ready to negotiate it according to the addressee's reaction. The motivation for ambivalence here may be to probe the risk, and if the risk is too high, to change the primary intent to a less risky one or even to leave the intent. Ambivalence may enable the speaker to keep the original intent from the addressee and avoid the responsibility for it.

As example (10) shows, when perlocutionary intent is not negotiable, the speaker has to reveal it if it is not understood by the addressee. When it is negotiable, however, the speaker may not reveal it even if the original perlocutionary intent is not achieved. Let us view some examples. A hospital legalist $(\mathrm{X})$ to Dan Morris, Ben's friend $(Y)$ :

(15) $\mathrm{X}$ : We have procedures...

$\mathrm{Y}$ : I understand, but she needs that heart or she's gonna to die! (Autumn in New York, 2000).

Another example shows the same pattern. Dr. Caddy $(X)$ to Dr. Wilson $(Y)$ :

(16) Y1: Twitter wants me to give House away.

X1: But you won't?

Y2: Is it a question or an order? (House M. D., 2004 - 2009).

Interlocutors do not reveal their original intent as it may not be achieved and thus the situation may turn to be risky. Here is one more example of such kind of ambivalence. Will $(X)$ is talking to Charlotte (Y):

(17) X1: What do you want for Christmas?

Y1: What's more important is what do you want for Christmas?

X2: No, you already gave me my present. What can I give you? (Autumn in New York, 2000).

In this case $X$ is sure that he can reach his original aim and that is why he insists on Y's even though she indirectly refused to answer at first.

Now that we have examined situations where perlocutionary intent is clear in the speaker's mind but negotiable let us turn to the so-called "socially tricky situations". A. Weiser [24] dwells upon "socially tricky situations" as of such when the original perlocutionary intent is especially risky, and ambivalence is advantageous to the speaker. With ambivalence, the speakers may show the negotiability of their perlocutionary intent, and give high optionality to the addressee. This enables the speaker to take the result as agreement and to avoid the responsibility for it.

See the following example which is the piece of conversation between $\mathrm{Mr}$. Hawthorne $(X)$ who is a member of the British Intelligence Service and $\mathrm{Mr}$. Wormold $(Y)$ who is a simple owner of the shop:

(18) X1: You go into the gents' and I'll follow you.

Y: But I don't want the gents'.

X2: Don't let me down. You're an Englishman, aren't you? (Our Man in Havana, 1959).

In this case $X$ actually wants to recruit $Y$ to work for the British Intelligence. At first, $Y$ doesn't understand X's hints (X1) that he wants to talk in private and the conversation is serious; $Y$ simply takes this utterance directly and refuses going to the gents $(Y)$. But $X$ insists and tries to make it clear that $Y$ must obey $(X 2)$.

The perlocutionary intent is clear in X's mind. Yet, he does not want to achieve it at the risk of damaging his own reputation and his relationship with $\mathrm{Y}$; that is why the perlocutionary intent is negotiable. Ambivalence enables $X$ to show the negotiability and to give the option to $Y$ how to take the X's utterance.

If $Y$ is willing to accept $X$ 's utterance as request or order or even threat, $X$ will be able to achieve his original perlocutionary intent. Even if not, however, $X$ does not have to admit that he failed to achieve it; he may continue the conversation quite naturally, pretending that he has never had such intent. Although $Y$ may suspect the intent, he will never be able to prove it; $X$ may avoid the responsibility and save face.

The next example shows the same pattern. Will $(X)$ and his friend John $(Y)$ are 
talking about his girlfriend:

(19) Y1: Anyway you look at it, one thing... treat her nice.

X1: What do you mean?

Y2: Treat her nice (Autumn in New York, 2000).

Although $Y$ treats $X$ 's girlfriend in a good way, he doesn't want to break his friendship with $X$. That is why he doesn't impose his own viewpoint upon $X$, he leaves the perlocutionary intent negotiable and thus $X$ can decide on his own how to take his friend's utterance.

In the next example Will (X) asks Charlotte $(Y)$ after she talked to a woman:

(20) X: Who was that?

Y: Lisa somebody (Autumn in New York, 2000).

$X$ 's utterance does not oblige $Y$ to answer directly - if she does not want to talk about that woman she can easily avoid this conversation. And she really avoids answering it the way she did.

One more example shows how addressee makes use of such utterances where the perlocutionary intent is negotiable. The owner of an asylum (X) talks to Mr. Thomas (Y):

(21) $\mathrm{X}$ : Look, I have a bonus coming in January. I just really need this 6-months extension...

Y: ... I will show myself out. I'll be in touch (Autumn in New York, 2000).

It is obvious that $Y$ is not willing to continue the discussion and to help $X$. That is why he takes X's utterance not as a request but as a simple statement. And thus he terminates the conversation.

Let us move on to situations in which perlocutionary intent remains unknown to the addressee. In many daily interactions it remains unknown to the other person what perlocutionary intent the speaker actually had in mind. In some cases, the speakers may even achieve a certain perlocutionary effect, keeping it unknown whether they actually had the intent or not. Here is an example. The wife $(\mathrm{X})$ asks her husband $(\mathrm{Y})$ :

(22) X: Would you like to go to the cinema and watch a film like in old good times?

Y: No, not really (Love Story, 1970).
Though X's utterance has a form of an alternative question, in fact, it is the example of strategic ambivalence, pure and simple. X's perlocutionary intended message, implied into the alternative question, is 'I want to watch a film'. But since it was disguised in the form of a question (and thus the perlocutionary intent kept negotiable), it is quite explicable that the perlocutionary intent was not understood by $\mathrm{Y}$ and $\mathrm{X}$ didn't achieve any perlocutionary effect.

Talking about $Y$, he simply took X's utterance literally, i. e., as a general question, which requires a direct answer 'yes' or 'no', and answered honestly "No, not really". This is the classic example of misunderstanding between men and women [6]. According to D. Tannen [21], men and women use different strategies of communication, which is the reason for the great amount of misunderstandings between them in daily interactions Thus, women use more indirect speech acts, while men tend to express themselves directly.

But misunderstandings in daily interactions are not limited only by menwomen interaction. It is possible to argue that all people are individuals and therefore use language individually, that is why ambivalence that occurs in communication causes a great number of failures to understand one another [19, p. 77]. Let us examine the next example. The conversation takes place at the supermarket where friends $X$ and $Y$ both want to buy the last pack of chips:

(23) X: Would you like them?

Y: Yes, I think I'll take them. Thanks (Meet Dave, 2008).

In this situation it is obvious that $Y$ failed to understand X's perlocutionary intent. Moreover, for $X$ it was not that important to get the last pack of chips; it was more important to negotiate his perlocutionary intent with $\mathrm{Y}$, to be polite and express friendliness. Yet, $Y$ couldn't offer the same to $X$ : although he got the last pack of chips, he didn't manage to express politeness and fidelity to $Y$ and, thus,

(C) I. V. Grabovska, I. V. Mariiko

«International journal of philology» | «Міжнародний філологічний часопис» Vol. 11, № 2, 2020 
increased the distance between them.

Another example shows how the addressee who didn't realize the speaker's perlocutionary intent managed to get himself out of the uncomfortable situation and switched to some abstract ideas in order not to look foolish. The patient's mother $(X)$ is talking to Dr. Chase $(Y)$ about her daughter's chances to recover:

(24) X: Is there any hope?

Y: There should always be hope (House M. D., 2004 - 2009).

$X$ 's utterance can be understood in different ways - as a simple question, as reproach, or as complaint (because of the wrong treatment). To avoid further misunderstanding, $Y$ switches to the abstract observation "There should always be hope" in order not to run into a conflict with $\mathrm{X}$ or disappoint her with bad news.

Discussion. Strategic ambivalence is typical for situations when the speaker has certain perlocutionary intent and is willing to achieve it. Two cases of strategic ambivalence are distinguished: a) when perlocutionary intent is clear in the

\section{References}

1. American beauty. (1999). DirectorSam Mendes. Scenario Alan Ball. DreamWorks SKG, USA.

2. Austin, J. L. (1962). How to do things with words. Oxford, Oxford university press, 168.

3. Autumn in New York. (2000). Director - Joan Chen. Scenario - Allison Burnett. Lakeshore Entertainment, USA.

4. Be kind rewind. (2008). Director Michel Gondry. Scenario - Michel Gondry. New Line Cinema, UK / USA.

5. Chkhetiani, T. D. (1987). Lingvisticheskie aspekty faticheskoy metakommunikatsii (na materiale angliyskogo yazyka) [Linguistic aspects of phatic metacommunication (a study of the English language)]. Candidate's thesis. Kiev, 203 [in Russian].

6. Coates, J. (1993). Women, men and language. Essex, Longman, 627.

7. Davis, L. H. (1979). Theory of action. Englewood cliffs, Prentice-Hall press, 213. speaker's mind and not negotiable; b) when perlocutionary intent is clear in the speaker's mind and negotiable.

In the first case, the motivation for ambivalence is to be more polite or present the intent in a less threatening manner. In other words, within this kind of ambivalence, regardless of the addressee's reaction, the speaker wants to achieve certain perlocutionary effect on the addressee that is not negotiable. The important point here is that the speakers do not have the intention to give the option to the addressees or to change their original intention.

In the second case, the motivation for ambivalence may be to see if the risk is high, and if so, to change the original intent to a less risky one, or if necessary, to leave the intent. In this kind of ambivalence, although the speakers have certain perlocutionary intent, they are ready to negotiate it according to the addressee's reaction. Strategic ambivalence may enable the speaker to keep the original intent from the addressee and avoid responsibility for it.

8. Goodwin, Ch. (2003). Conversation and brain damage. London, Oxford university press, 132.

9. Grabovska, I. V. (2014). Metakomunikatyvni pytannia $\mathrm{v}$ suchasnomu anglomovnomu dialogichnomu dyskursi: semantyka i pragmatyka [Metacommunicative questions in modern English dialogic discourse: semantics and pragmatics]. Candidate's thesis. Kyiv, KNLU, 223 [in Ukrainian].

10. House, M. D. (2004-2009). Director Deran Sarafian, Greg Yaitanes, David Straiton et al. Scenario - David Shore and others. Universal media studios, USA.

11. Keller, E. (1981). Gambits: conversational strategy signals. Conversational routine. The Hague, Mouton, 1-17.

12. Leech, J. (1983). Principles of pragmatics. London, Longman, 250.

13. Love story. (1970). Director - Arthur Hiller. Scenario - Erich Segal. Love story company, USA.

14. Lyons, J. (1984). Semantics. 
Cambridge, Cambridge university press. Vol. 2, 897.

15. Meet Dave. (2008). Director - Brian Robbins. Scenario - Rob Greenberg, Bill Corbett. Twentieth century fox film corporation, USA.

16. Our man in Havana. (1959). Director - Carol Reed. Scenario - Graham Greene. Kingsmead productions, UK.

17. Searle, J. R. (1969). Speech acts: an essay in the philosophy of language. Cambridge, Cambridge university press, 120.

18. Seven pounds. (2008). Director Gabriele Muccino. Scenario - Grant Nieporte. Columbia pictures, USA.

19. Sinclair, J. (1980). Discourse in relation to language structure and semiotics. London, Longman, 115.
20. Tanaka, N. (2001). The pragmatics of uncertainty. Journal of pragmatics. No. 12, 121-142.

21. Tannen, D. (1990). You just don't understand: women and men in conversation. New York, Morrow publishers, 330.

22. Thomas, J. A. (1992). Handouts for the lecture: pragmatics. Lancaster, Lancaster University, 55.

23. Thomas, J. A. (1986). The dynamics of discourse: a pragmatic analysis of confrontational interaction. Lancaster, Lancaster University, 213.

24. Weiser, A. (1974). Deliberate ambiguity. Papers from the 10th meeting of the Chicago linguistic society. Chicago: Chicago university press, 723-731.

\section{СТРАТЕГІЧНА АМБІВАЛЕНТНІСТЬ В ІЛЛОКУТИВНИХ МОВЛЕННЄВИХ АКТАХ СУЧАСНОГО АНГЛОМОВНОГО ДІАЛОГІЧНОГО ДИСКУРСУ \\ І. В. Грабовська, І. В. Марійко}

Анотація. У статті розглянуто стратегічну амбівалентність в іллокутивних мовленнєвих актах. Визначено прагматичні особливості стратегічних амбівалентних іллокутивних мовленнєвих актів сучасного англомовного діалогічного дискурсу. Встановлено, що стратегічна амбівалентність $є$ характерною для ситуацій, у яких мовець має чіткий перлокутивний намір та хоче вплинути певним чином на слухача. Виділено два випадки виявлення стратегічної амбівалентності: а) коли перлокутивний намір зрозумілий мовцю і не може слугувати предметом обговорення; б) коли перлокутивний намір зрозумілий мовцю i може слугувати предметом обговорення.

Ключові слова: амбівалентність, іллокутивний мовленнєвий акт, стратегічна амбівалентність, теорія мовленнєвих актів, перлокутивний намір. зв'язку. 